\title{
ROMANCING MASCULINITIES IN UTSANA PHLEUNGTHAM'S THE STORY OF JAN DARA: A THAI LITERATURE
}

\author{
Darsono $^{1}$, Desca Angelianawati ${ }^{2}$ \\ ${ }^{1}$ Department of History Education \\ darsono@upy.ac.id \\ ${ }^{2}$ University of PGRI Yogyakarta \\ descang@upy.ac.id
}

\begin{abstract}
In several Thai folktales and so-considered classic literature like the Legendary Tale of Krai Thong and the Legend of Phra Chao Sua, the heroes and the warriors present themselves as a masculine creature. Their manly assets including body and gesture have become the exploitation of the story whilst being the model of masculinity. Utsana Phleungtham's two main male characters in the novel the Story of Jan Dara are without exception. Those heroes of the story portray male masculinities through their existence and domination. Undertaking qualitative research in the novel and the library studies, this article illustrates how male masculinities are depicted and why it is manifested though the main male characters in Utsana Phleungtham's The Story of Jan Dara. The findings show that the male masculinities are presented vividly in order to maintain the rooted masculine domination and patriarchal system.
\end{abstract}

Keywords: Thai literature, The Story of Jan Dara, Utsana Phleungtham, male masculinities

\section{INTRODUCTION}

The issue of gender role, mainly concerning association of men with masculinities and women with femininity remains a notable issue. The prevalence of gender role can eb seen in how the interdisciplinary interest on men and masculinities has also increased worldwide (Richardson and Robinson, 2008) in which the research on those matters has a grown rapidly since the mid of 1980s (Whitehead, 2010). Sharyn Davies, Krisna Sen and Marshall Clark are examples of scholars who write about gender including male and masculinities from broader perspectives. Masculinity itself is often defined as a set of behaviour, roles and attributes which are associated with men and is believed as a social construction (Macan Ghail \& Haywood, 2006; Shehan, 2018). The discussion about those topics will likely cover the subjects and their relation to the social class,

\section{British, Jurnal Bahasa dan Sastra Inggris}


globalization, gender, sexuality and others. Masculinities are produced through the work in which body, social practices, cultural arenas, and institutional sites are involved (Haywood \& Macan Ghail, 2006: 30). Therefore, masculinities related to one's body or sexuality has been the most favourable topics for more than two decades (Woodward, 2008: 75).

"Over the last twenty years 'the body has become a major concern of academic study... it has been a central to activists' campaigns, especially those associated with 'identity politics,'...people sought to take control over their own sexuality, reproductive rights, and to gain freedom from harassment and acts of racism and aggression."

Positioning the notion of masculinity in male bodies and femininity in female bodies, the gender analysis mainly concerns about female aspects. While women's bodies tend to be the common centre for scholars' analysis, the discussion about men and their attributes are often neglected. Women and their attribute have become the main commodities to be exploited through media, literature and cultural products like cosmetics and beauty products. On the other hand, men's attributes and their association with beauty are not socially constructed to form 'ideal masculinity' as expected by the society. The reason is simply because associating men and masculinities with beauty is not considered as a part of most-accepted heterosexual community.

The idea is a contradictive concept because masculinities should cover all aspects in men including how they act, think, believe and appear or made apparent (Hearn and Parkin, 2006:7). The association of male with beauty is similar to the association of women with manly apparent. Women will be likely referred as a tomboy whenever her conduct of behaviour resembles a man. Meanwhile, a man will be associated with homosexuality when they are beautifying themselves through beauty products. This is debatable because there are many heterosexual men who will put more efforts and spend more money in order to maintain their beauty including those so-called metrosexual men (Ghaill, 1996).

Returning to the discussion about men and masculinities, the study can be divided into three main waves (Edwards, 2006: 79). The development of sex role

\section{British, Jurnal Bahasa dan Sastra Inggris}


models to question the definition of masculinity has become the main concern in the first study in the 1970s. In the 1980s, the second wave of study focuses on the development of masculinity. In this particular time, the definition is based on the challenge that taking masculinity should be seen not only from the middle-class western and white masculinities but also from the colour men, gays and those coming from the working class. The main concentration in this period of time is to analyse masculinities and to circle it around power, its complex meanings and how they operate. Meanwhile, the last wave in the 1990s is mostly influenced by the post-structuralists. The discussions are likely related to the gender performativity, normativity and sexuality itself. Those discussions are also related to literary, cultural, media and social studies. As for masculinity, the recent emphasis is on being dependent and fluid.

The notion of masculinities used to represent the male characters of this novel is likely belong to the third wave study. It is because of its relation to the normativity, sexuality and performativity. The cultural possibilities of sexual violence against men, the media representations, social and cultural transformation through language and education led to a fabrication of what it means to become a man including male masculinities (Haywood and Ghaill, 2006: 13). The values of masculinities will be valued and seen inversely in different society. In addition, the portrayal of masculinities has changed rapidly throughout different periods of time but can be roughly divided into two categories: the traditional man and the new man.

Traditional men are recognised through their physical aggressiveness. They are not emotionally sensitive or self-revealing. They develop male bounds with no intimacy because they prefer to have a male companion. The traditional men tend to see marriage as a necessity; therefore, they see women either as good or bad girl. They also have sexual double standards. In the contrary, in the new portrayal of male masculinities and metrosexual men; a man is expected to be intelligent and have interpersonal skills. They should be emotionally sensitive, economically well-off, and more expressive with women. Therefore, masculine metrosexual men are assumable to prefer the company of women. They seek a source of

\section{British, Jurnal Bahasa dan Sastra Inggris}


support from their heterosexual relationship. They believe in equal relationship and see marriage as a romantic journey. They are less prejudice towards sex because they see women more as an individual (Simpson, 1994; Simpson, 2013). In addition to that matter, men also occupy a hegemonic masculinity in order to secure their position of superiority (Ford and Lyons, 2012: 10). Men have the tendency to maintain their position in the society through their domination (Bourdieu, 1998). One of the ways to do so is to keep showing and maintaining their masculinity.

As aforementioned, masculinity is a performed social identity; therefore, a man may feel the urge to perform certain tasks. Those social and cultural tasks later will determine his position in society. These kinds of performance are more problematic for men because the social expectations they experience is higher than women. In the masculine identity formation, a man will likely undergo the social expectations of power, strength and sexual competence (Pleck, 1981; Haywood and Macan Ghill, 2006). When a man is able to pass those stages successfully, he is rewarded a certain position in the society. It shows that male masculinities play an important role in leading one to a notion of male domination and male power in the society. It is also important to maintain the patriarchal culture.

To contribute toward enriching the discussion of masculinity, this study analyses Utsana Phleungtham's novel The Story of Jan Dara. A notable aspect concerning this novel is how the main character possesses several traits of masculinity aforementioned. By studying the representation of masculinities in the novel, this article illustrates how masculinities are depicted through two main characters of the novel: Khun Luang and Jan Dara themselves. The depiction later is used to unveil the purpose of maintaining masculinities in the novel.

\section{RESEARCH METHOD}

The emphasis of this article is to explore the male masculinities and its purpose as depicted in Utsana Phleungtham's The Story of Jan Dara. To analyse the portrayal of masculinities, this article follows the descriptive-qualitative

\section{British, Jurnal Bahasa dan Sastra Inggris}


approach and focuses more on the interpretation. Meanwhile, the approach used in this study is an objective approach. The object is analysed through a process of repeated readings. The library study is taken to classify the data. The data of the article is gathered through the analysis of words and sentences in the novel.

The object is a novel written in 1966 by Utsana Phleungtham, a Thai writer entitled Rueang Khong Jan Dara or is simply translated as The Story of Jan Dara in English. The novel is translated into English by Phongdeit Jiangphatthanarkit and is edited by Marcel Barang. It tells a story about a boy named Janrai Witsanan. He grows up in a dysfunctional but wealthy family where debauchery impacts everyone's lives in 1930s Siam. Janrai is cursed by his father because his mother died during his childbirth. The abusive Khun Luang Wisnan, mostly referred as His Lordship in the novel; is a womaniser who has sexual intercourse with every woman in the household including Aunt Waad. The young Jan is jealous because he has a deep feeling for his aunt. Aunt Waad and His Lordship later married and they have a daughter named Kaew. She becomes the apple of His Lordship's eyes. Khun Luang spoils and teaches Kaew to hate Jan by referring him as the 'Jan Dara' - the bastard Jan. In the contrary, Aunt Waad treats Jan like her own son.

Khun Luang's women, the sophisticated Ms. Boonleaung later moves into a guest house on their estate. She will be the one who teaches Jan his first lesson in ways of love. Yet Jan is later being framed for raping Kaew who was having a sexual relation with the son of one the family's maids. Jan ends up being punished for Kaew's transgression and is moved to live with his grandmother. However, Kaew is later pregnant with the seed of her own father. To smooth over the damage to the family's reputation, Jan is asked to return and is forced into an arrange marriage with Kaew. He does so, as long as he is promised the deed to the estate which he sees as a form of vindication against his father.

Kaew then gives a birth to Khun Luang's child and curses the baby after he has emerged from her womb. The child suffers from down syndrome. Kaew does not change her lifestyle since then. She even enters the same-sex relationship with Ms. Boonleaung whom Jan Dara happens to have a romantic relationship with.

\section{British, Jurnal Bahasa dan Sastra Inggris}


Jan discovers this and demands Kaew to bear him a child. He forces himself to Kaew until Kaew is pregnant. Kaew refuses to have the baby and with Ms Boonleaung's assistance, she performs a bloody self-administered abortion. Jan lately finds out that he keeps repeating Khun Luang's libidinous patterns by having sexual intercourse with a maid in his father's living room in front his mother's portrait. Jan wonders why he cannot escape the cycle of sexual abuse started by his father. It is later in the second sequel reveals that Jan is also the product of a gang rape of his mother.

The story is full of revenge and debauchery; therefore, the novel is considered as one of erotic literature. The story of Jan Dara written by Phleungtham is adopted into a movie on 20 September 2012. The famous Thai-German actor Mario Maurer and Bongkot Kongmalai have starred the movie. The movie wins several movies nominations leaving \$1,358,865 as a cumulative worldwide gross (An IMdb Article, 2012). Based on its fame, a sequel is made in 2013 and was also successfully launched.

\section{RESEARCH FINDING AND DISCUSSION}

This section concerns with analysing the notion of masculinity in the Story of Jan Dara. It should be highlighted that Thai literature, as an example of Thai cultural heritage conveys the aesthetic notion of beauty. Male and female as the main characters should be portrayed beautifully. The literature also presents both men and their bodies. The Story of Jan Dara is without exception toward the prevalence of beauty of both male and female character.

Through the short summary aforementioned, one can see the portrayal of traditional masculinities. The traditional portrayal is represented by the aggressiveness of the male characters of this novel which are Khun Luang Witsanan and Jan Dara themselves. Their behaviour does not only confirm this notion but also confirm that they are the portrayal of traditional male masculinities in Thai society at that particular time.

Jan Dara also prefers the male companions as women are often considered as the commodities portrayed with the homoerotic friendship between Khun Jan

\section{British, Jurnal Bahasa dan Sastra Inggris}


and Ken. Both of them develop a homoerotic relationship which is a strong male bound yet there is no intimacy nor sexual relationship between them (Lilly, 1993). In the traditional view of masculinities, men tend to see marriage as a necessity. As what Ms. Boonlueang says to Jan Dara when he asks about marrying her;

"So, no real wife for me in this life?"

"A wife? What's so important about a wife, now that you've got everything, much more than you could hope to get from any wife? You've got everything from your beloved Aunt Waad and from me - everything except the word 'wife' which will happen to belong to Ms. Keaw.

"What would happen if I fell in love with someone else?" I (Jan Dara) asked in order to torture myself a little.

"When you are in love, you'll get that love: if she loves you in return, you'll get love from her and you can give her everything you own except the word 'wife.' When that time comes, do you think this will matter more than everything else? (Phleungtham, 1995: 175)

From the dialogue between Ms. Boonleuang and Jan Dara, it is obvious that people tend to see marriage as an unimportant subject in a man's life. It also means that marriage is nothing but a media to prolong the family name in which the women carry the obligation to bear the children and conduct themselves in the right manner as a domesticated housewife. This notion confirms the portrayal of male and masculinities at that particular time.

Jan Dara's description on his wife, Keaw represents the traditional view of men. Jan always represents his wife as;

“... Of course, no matter how evil we are, we all have a little bit of good in ourselves. Wilareik Witsanan, too, had a good side, inasmuch as she sometimes became kind-hearted. She could love and knew how to wish people well and show concern for others. So, when she fancied someone, she lavished her love unstintingly, totally oblivious to any other considerations and this created no end of trouble for other people." (Phleungtham, 1995:47)

Through Jan's description towards his wife one cannot see the tendency of seeing a woman from her good and bad side. Even though Jan describes her wife as an evil woman, she is also portrayed with her good side. Therefore, Jan fails to fill the characteristic of a traditional men in that era.

It is also interesting to put the character of Khun Luang and Jan Dara in the spotlight. As aforementioned, they prefer to have a male companion rather than

\section{British, Jurnal Bahasa dan Sastra Inggris}


female companion in their social life. Meanwhile, Khun Luang and Jan Dara will always go for female companions in order to gratify their sexual desire. Their complicated sexual relationship with Ms. Boonlueang is the example. This debauchery is the evidence that both of these characters have a sexual double standard which refer to the portrayal of male masculinities in the past. Yet it also portrays the modern masculinities in which they prefer the companion of a woman in the pleasure department while socialising with their male friends.

Through those two main male characters, one can see a huge effort in maintaining the male sexuality and masculinity. The debauchery conducted by Jan Dara and Khun Luang is one of the examples. By showing that they are the one holding out the power in the pleasure department, they also present their image as a masculine man.

Another example of masculinity is when Jan decides to take a revenge towards his father. The family wants Jan to take a responsibility after Kaew is impregnated by His Lordship. Jan has agreed to do so with a condition and he does it out of revenge towards his father who banishes him. Jan says;

“..There must be something in exchange - a compensation..." (Phleungtham, 1995:144)

The compensation which Jan's wanted is a compound of his late mother where Khun Luang lives in. This kind of masculinity is meant to humiliate Khun Luang and to gain more symbolic capital in order to be more powerful than Khun Luang. Whether Khun Luang likes it or not, he will have to beg Jan to cover his shameful behaviour towards his daughter.

In addition, Jan shows a kind of masculinity when he intentionally seduced Ms. Boonlueang to prolong their sexual relationship. They had a carnal relationship until Khun Luang finds out. This discovery causes Khun Luang to have a heart attack and he becomes half-paralysed. He no longer is able to perform his duty to please Ms. Boonluang- his mistress sexually. In this stage, Jan Dara successfully shows his masculinity through revenge. It also confirms Haywood and Macan Ghill (2006)'s opinion that a man who is successfully able

\section{British, Jurnal Bahasa dan Sastra Inggris}


to maintain his masculinities will gain certain status or power in the society. They will also maintain masculinities by subordinating others. Jan Witsanan is successfully doing so.

Jan also shows his masculinity out of anger and revenge when he finds out that Kaew also has a sexual relationship with his mistress, Ms. Boonlueang. Jan asks Kaew something in return which is the baby of his own. When Kaew rejects his request, he sexually harassed Kaew in order to maintain his masculinity. Another reason is to position himself as someone who is powerful than Kaew.

"My anger this time know no bounds. It made me burn with the sudden blind lust, and right on the floor I performed on her what criminal law calls rape..." (Phleungtham, 1995: 235)

Their main occupation is also a way to show how masculine and powerful they are. Khun Luang is portrayed as an important high-rank officer at the Ministry of Interior (Phleungtham, 1995: 10) while Jan is portrayed as a successful businessman (Phleungtham, 1995: 190). They have their assets and status in the society as both are respected. It means that their portrayal of masculinity: well-off and well-educated leads them to the notion of masculine domination. They show that their status is symbolically higher than other common people.

Based on those aforementioned explanations, one can see that the main male characters in Utsana Phleungtham's The Story of Jan Dara fit into the description of traditional and modern masculinities. Both of them also have shown certain type of masculinities through their symbolic statuses. Those symbols include their status in the society, their wealth, and their sexuality. The novel shows that those characters mostly maintain their masculinity in the most sexual way which is through debauchery. Those symbols of masculinity later show that they are used in order to maintain the social position as a man. It is also to establish their position as a powerful man by subordinating others. In conclusion, those purposes lead them to legitimise the patriarchal culture they live in.

\section{British, Jurnal Bahasa dan Sastra Inggris}




\section{CONCLUSION AND SUGGESTION}

The novel The Story of Jan Dara written by Utsana Phleungtham does not only enrich the Asian literature particularly the erotic literature but also offers new perspectives to its readers. This erotic novel shows a vivid portrayal about male and masculinities which has become an interesting topic to study recently. The narration about male and masculinities is either explicitly or implicitly shown to strengthen the characters of the novel.

In its relation to the notion of male masculinities, the two main characters in this novel which is Khun Luang and Jan Dara have shown their masculinity vividly. They belong to the categorisation of traditional and modern masculinities. It because they rather keep a male companion and tend to see women as a commodity to gratify their sexual desire only. Yet their masculinity through the acts of debauchery and through their socio-symbolic like their occupation show that they also fit the category of new and modern masculinities.

Those symbols of masculinities they have shown later lead them to the discussion about the purpose of maintaining masculinities. The novel shows that either Khun Luang and Jan Dara tend to maintain masculinities through their behaviour to show that they have higher capital than others. The purpose is for subordinating and taking control of others. They are able to assert more masculinity and legitimise their power through a masculine domination. They are also able to legitimise the pratriarchal culture by doing so.

\section{REFERENCES}

David, D. S., \& Pleck, J. H. (1983). The Myth of Masculinity. Contemporary Sociology. https://doi.org/10.2307/2068233

Edwards, T. (2005). Cultures of masculinity. In Cultures of Masculinity. https://doi.org/10.4324/9780203005224

Ford, M., \& Lyons, L. (2012). Men and masculinities in Southeast Asia. In Men and Masculinities in Southeast Asia. https://doi.org/10.4324/9780203197394

\section{British, Jurnal Bahasa dan Sastra Inggris}


Ghaill, M.M. 1996. Understanding Masculinities. Buckingham: Open University Press.

Haywood, C and Ghaill, M. M. 2006. Men and Masculinities: Theory, Research and Social Practices. Philadelphia: Open University Press.

Hearn, J. and Parkin. W. 2006. Gender, Sexuality, and Violence in organisation. London: Routledge.

IMDBPro. 2012. Jan Dara: The Beginning. (https://www.imdb.com/title/tt2599106/. Accessed on 6 July 2020).

Lilly, M. 1993. Gay Men's Literature in the Twentieth Century. New York: NY Press.

Phleungtham, U. 1995. The Story of Jan Dara. Bangkok: TMC.

Richardson D., and Robinson, V. 2008. Introducing Gender and Women's Studies. Hampshire: Palgrave Macmillan.

Shehan, C. 2018. Gender Roles in American Life. Brighton: ADC-CLIO Publishers.

Simpson, M. 1994. "Here Come the Mirror Men." An article at The Independent UK published on 15 November 1994. (https://marksimpson.com/herecome-the-mirror-men/. Accessed on 7 July 2020).

Simpson, M. 2013. Metrosexy: A $21^{\text {st }}$ Century Self-Love Story. New York: Createspace Independent Publishing Platform.

Uhlmann, A. J., Bourdieu, P., \& Nice, R. (2002). Masculine Domination. Contemporary Sociology. https://doi.org/10.2307/3089075

Woodward. K. 2008. Gendered Bodies: Gendered Lives. Hamshire: Palgrave Macmillan.

\section{British, Jurnal Bahasa dan Sastra Inggris}

